\title{
SHARE OF DIETARY SUPPLEMENTS IN NUTRITION OF COELIAC DISEASE PATIENTS*
}

\author{
Julita Reguła $\bowtie$, Angelika Śmidowicz \\ Department of Human Nutrition and Hygiene, Poznań University of Life Sciences \\ Wojska Polskiego 31, 60-624 Poznań, Poland
}

\begin{abstract}
Introduction. The aim of the study was to assess the intake of vitamins and minerals from the food ration and levels recorded after synthetic supplementation in patients following a gluten-free diet.

Material and methods. The study included a cohort of 25 individuals aged 20-54. Nutrient intakes were assessed based on a 24-hour diet recall interview and an original questionnaire prepared by the authors specifically for this study. Anthropometric measurements were recorded in order to assess the nutritional status of the patients.

Results and discussion. A low energy intake and an excessive share of fat were observed in daily food rations of coeliac disease patients. Uptake of most minerals with the diet was too low, while that of vitamins too high. Most participants declared the administration of supplements, which greatly contributed to the coverage of requirements for these nutrients.

Conclusions. It was observed that the administered supplementation was frequently unjustified, which led to the allowances being considerably exceeded for many vitamins and minerals.
\end{abstract}

Key words: nutrients, gluten-free diet, minerals, eating habits

\section{INTRODUCTION}

Coeliac disease is an autoimmune gluten-sensitive enteropathy of the small intestine occurring in genetically predisposed individuals [Tack et al. 2010, Lionetti and Catassi 2011], leading to villous atrophy and as a consequence to maldigestion and malabsorption [Szajewska 2007, Grzymisławski et al. 2010, Megiorni and Pizzuti 2012]. The disease is manifested following exposure to gluten, a prolamin fraction of cereal proteins (gliadin in wheat, secalin in barley, hordein in rye) [Szajewska 2007], thus the only effective form of treatment is a life-long gluten-free diet
[Tack et al. 2010]. Gluten-free diet consists in the absolute elimination from the diet of gluten-containing cereals, i.e. wheat, rye, barley (consumption of oats is disputable) as well as products containing gluten [Grzymisławski et al. 2010].

Most products from gluten-free cereals (rice, maize, sorghum, proso millet, manioc, quinoa, amaranthus) have lower nutritive values than their counterparts produced from cereals containing gluten [Grzymisławski et al. 2010]. Moreover, a gluten-free diet is frequently monotonous and imbalanced, potentially leading to

\footnotetext{
*The study was partially supported by National Science Centre (NCN) Grant OPUS no. 2011/01/B/NZ9/00130.

凶umar@up.poznan.pl 
quantitative and quality malnutrition [Kliniczne... 2008]. Patients are often observed to suffer from deficiencies of folic acid, vitamins $\mathrm{A}, \mathrm{D}, \mathrm{E}$ and $\mathrm{C}, \mathrm{Fe}, \mathrm{Ca}$, $\mathrm{Mg}$ and $\mathrm{Zn}$, resulting both from an imbalanced diet and disturbed absorption [Hozyasz et al. 2003, Gomułka and Demkow 2010, Scalon and Murray 2011].

As a result of the above mentioned problems and the belief that gluten-free diet is inadequate, coeliac disease patients frequently use dietary supplements. Supplements may constitute a valuable addition to gluten-free diet [Lemkin 2003]. Numerous researchers stress the fact that supplementation should be administered only when deficiencies have been diagnosed [Hozyasz et al. 2003, Autodore and Muralidhar 2009].

Thus it seems essential to monitor intake of minerals and vitamins from daily food rations (DFR) including supplementation, since their excessive intake may lead to accumulation of these compounds and the resulting side-effects. For this reason it was the aim of this study to assess the percentage of reference daily intake with DFR, as well as the levels in the case of supplementation administered by patients following a gluten-free diet.

\section{MATERIAL AND METHODS}

Analyses were conducted on a cohort of 25 individuals (23 females and 2 males) aged 20-54 years, members of the Polish Coeliac Society. The protocol of the study was approved by the Research Ethics Committee of the Poznan University of Medical Sciences and registered at no. 888/11.

Nutrition status was estimated based on anthropometric measurements (body weight, height) and body mass index (BMI) calculated on their basis.

Information concerning administration of glutenfree diet, occurring deficiencies and supplementation was collected using a questionnaire designed specifically for the purpose of this study.

The diet was assessed based on a 24-hour diet recall interview consisting in recording the amounts and types of consumed foodstuffs and drinks. The Photo Album of Foodstuffs and Dishes, developed by the National Food and Nutrition Institute was used to accurately determine the size of servings [Szponar et al. 2000]. Energy value and nutrient contents in daily food rations (DFR) of patients including supplements or their lack were calculated using the Dietetyk computer programme. Obtained values were compared with the recommended dietary allowances respective for a given sex, age, body weight and physical activity [Jarosz 2012], while the mean percentage of reference daily intake was determined.

It was assumed in this study that proteins, carbohydrates and fats should account for $15 \%, 55 \%$ and $30 \%$ energy value of a diet, while saturated fatty acids (SFA), monounsaturated fatty acids (MUFA) and polyunsaturated fatty acids (PUFA) should supply $8 \%$, $14 \%$ and $7 \%$, respectively, of daily energy requirement. The upper limit for cholesterol intake was established at $300 \mathrm{mg}$. When assessing the percentage of reference daily intake a maximum deviation from the allowance was assumed to be $\pm 15 \%$.

\section{RESULTS AND DISCUSSION}

Anthropometric parameters of the coeliac disease patients are presented in Table 1. It was shown that the mean value of body mass index (BMI) fell within the standard values. However, classifications of individuals in terms of this index (Fig. 1) showed that a considerable percentage of patients was underweight. Overweight and obesity were observed in a very small number of the participants. Consistently with the research results, the nutrition status of coeliac disease patients differed significantly from that in the population of healthy individuals. Inadequate body weight in coeliac disease patients was also stressed in studies by Kostrzewska et al. [2007] and Bardella et al. [2000]. In contrast, a greater percentage of overweight and obese individuals is found in the healthy population, while the problem of underweight is minor [Jóźwiak 2008, Janus and Reguła 2011].

Table 1. Anthropometric parameters of participants

\begin{tabular}{lc}
\hline \multicolumn{2}{c}{ Parameter } \\
\hline Height, cm & $165.9 \pm 5.3$ \\
Body mass, kg & $58.7 \pm 11.7$ \\
BMI & $21.3 \pm 4.2$ \\
\hline
\end{tabular}



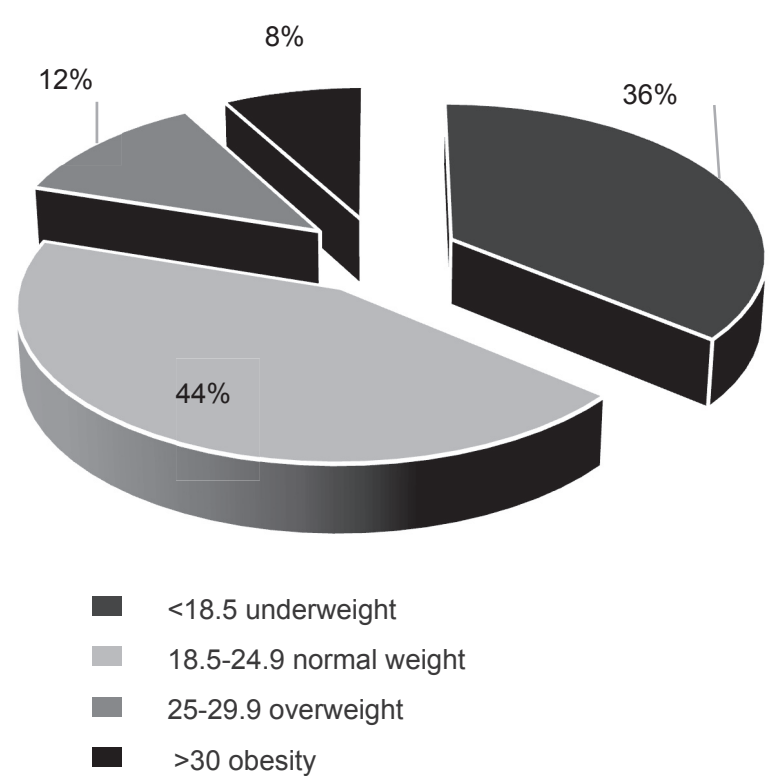

Fig. 1. Classification of patients in terms of BMI

All the patients followed a gluten-free diet, although the age at which they introduced it and the diet duration varied. A considerable proportion of the participants (44\%) introduced a gluten-free diet at the age of 20-29 and at the age of 1-9 years (16\%). An identical proportion of the patients ( $8 \%$ each) started to follow a gluten-free diet at the age of 30-39 years and over 49 years. Most of the participants used the elimination diet for a period shorter than 1 year (36\%) and from 1 to 5 years $(14 \%)$, while $12 \%$ patients followed the diet for 5-20 years and an identical number of the participants used it for over 20 years.

A vast majority of patients (80\%) declared the administration of dietary supplements. Other studies on various populations also showed a high percentage of individuals using diet supplementation [Król et al. 2005, Schlegel-Zawadzka and Barteczko 2009]. Statistics from the USA also reported that most adult Americans $(75 \%)$ use dietary supplements [Szotowa 2001].

Figure 2 presents data concerning supplementation depending on the duration of gluten-free diet. Similar proportions of individuals using supplements and not using supplementation were recorded among patients following a gluten-free diet for less than 1 year, for a period of 1-5 years and for more than 20 years. In turn, in the group of patients following a gluten-free

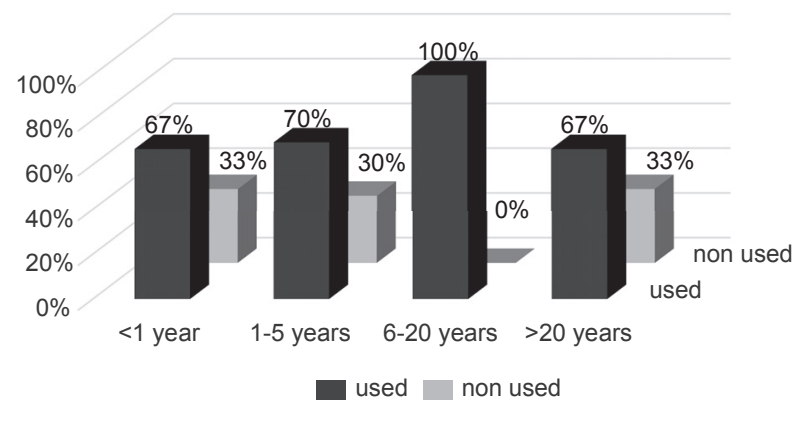

Fig. 2. Supplementation and the duration of gluten-free diet

diet for 6-20 years all the participants declared dietary supplement administration. Among the patients using supplements, a majority ( $45 \%$ ) used them for reasons not connected with the coeliac disease, e.g. folic acid supplementation by women planning pregnancy. A considerable percentage of the participants $(40 \%)$ used supplements based on the doctor's advice in order to alleviate deficiencies. It was also observed that a considerable group of the participants $(15 \%)$ used supplements as a prophylactic measure. This probably resulted from the belief that a gluten-free diet is imbalanced and poor in nutrients. However, it needs to be stressed that a gluten-free diet may provide all essential nutrients on condition it is adequately balanced. In a study by Schlegel-Zawadzka and Barteczko [2009] an even greater group (66\%) used supplements unconsulted with a doctor.

Most frequently patients used supplements containing vitamins $\mathrm{D}(44 \%), \mathrm{E}(40 \%)$ and $\mathrm{B}_{6}(36 \%)$ as well as $\mathrm{Mg}(40 \%)$. A considerable group (32\%) also used preparations containing vitamins $\mathrm{A}, \mathrm{B}_{1}, \mathrm{~B}_{2}, \mathrm{~B}_{12}, \mathrm{C}$ and folic acid, as well supplements containing iron (24\%), calcium $(20 \%)$, zinc $(20 \%)$ and potassium $(16 \%)$. Only two patients used phosphorus supplementation.

Since the onset of gluten-free diet most participants $(56 \%)$ declared the incidence of vitamin and mineral deficiencies. The most frequently observed deficiencies concerned vitamin $\mathrm{B}_{12}$, iron and magnesium (24\%), vitamin D and potassium (20\%). Deficiencies of vitamins $\mathrm{B}_{6}(16 \%)$ and $\mathrm{A}(8 \%)$, calcium and sodium $(8 \%)$ were reported less frequently, while deficiencies of phosphorus, zinc and vitamin E were rare (4\%). Observed deficiencies were mostly correlated with an insufficient supply of these nutrients in the diet. 
Table 2 presents percentages of reference daily intake for macronutrients. It was shown that the intake of energy and carbohydrates was markedly too low. The insufficient supply of energy is manifested in the high percentage of underweight individuals in the examined group. The distribution of energy in terms of macronutrients was also disadvantageous. The share of energy from carbohydrates was found to be low in relation to energy coming from fat. Moreover, the ratio of fatty acids was markedly adverse. Most fatty acids in the diet were SFA and the share of PUFA in energy intake was definitely too low. Moreover, dietary fibre intake was insufficient. These studies correspond with the results reported by Bardella et al. [2000] for a group of 71 coeliac disease patients. Similarly, a too low energy value of DFR and a low share of energy from carbohydrates in relation to that from fat was

Table 2. Percentages of reference daily intake for macronutrients

\begin{tabular}{lc}
\hline \multicolumn{1}{c}{ Nutrient } & $\%$ RDI \\
\hline Energy, KJ & 79 \\
Energy, kcal & 79 \\
Protein, g & 89 \\
Fat, g & 92 \\
Carbohydrates, g & 69 \\
Sucrose, g & 85 \\
SFA, g & 111 \\
MUFA, g & 77 \\
PUFA, g & 54 \\
Protein, \% E & 112 \\
Fat, \% E & 116 \\
Carbohydrates, \% E & 88 \\
SFA, \% E & 135 \\
MUFA, \% E & 99 \\
PUFA, \% E & 73 \\
Cholesterol, mg & 93 \\
Dietary fiber, g & 79 \\
\hline
\end{tabular}

reported in a study on a group of healthy university students [Marzec et al. 2012].

Table 3 presents the percentage of reference daily intake with DFR for vitamins and minerals including administration of dietary supplements and its lack. An insufficient intake with DFR was recorded for most minerals (sodium, potassium, calcium, magnesium and iron), while intake of phosphorus and copper exceeded the upper limits of RDI. Only zinc intake met the reference intake value. A low intake of magnesium in the examined group is also confirmed by the results

Table 3. Percentages of reference daily intake for selected minerals and vitamins in patients including supplementation or its lack

\begin{tabular}{|c|c|c|}
\hline \multirow{2}{*}{ Nutrient } & \multicolumn{2}{|c|}{$\%$ RDI } \\
\hline & no supplementation & with supplementation \\
\hline \multicolumn{3}{|l|}{ Minerals } \\
\hline $\mathrm{Na}, \mathrm{mg}$ & 84 & 84 \\
\hline $\mathrm{K}, \mathrm{mg}$ & 66 & 67 \\
\hline $\mathrm{Ca}, \mathrm{mg}$ & 56 & 68 \\
\hline $\mathrm{P}, \mathrm{mg}$ & 157 & 159 \\
\hline $\mathrm{Mg}, \mathrm{mg}$ & 79 & 107 \\
\hline $\mathrm{Fe}, \mathrm{mg}$ & 52 & 71 \\
\hline $\mathrm{Zn}, \mathrm{mg}$ & 102 & 124 \\
\hline $\mathrm{Cu}, \mathrm{mg}$ & 116 & 116 \\
\hline \multicolumn{3}{|l|}{ Vitamins } \\
\hline $\mathrm{A}, \mu \mathrm{g}$ & 120 & 147 \\
\hline $\mathrm{D}, \mu \mathrm{g}$ & 69 & 128 \\
\hline $\mathrm{E}, \mathrm{mg}$ & 97 & 154 \\
\hline $\mathrm{B}_{1}, \mathrm{mg}$ & 93 & 128 \\
\hline $\mathrm{B}_{2}, \mathrm{mg}$ & 127 & 164 \\
\hline $\mathrm{PP}, \mathrm{mg}$ & 136 & 157 \\
\hline $\mathrm{B}_{6}, \mathrm{mg}$ & 173 & 228 \\
\hline Folates, $\mu \mathrm{g}$ & 48 & 74 \\
\hline $\mathrm{B}_{12}, \mu \mathrm{g}$ & 159 & 192 \\
\hline $\mathrm{C}, \mathrm{mg}$ & 93 & 147 \\
\hline
\end{tabular}


reported by other authors for cohorts of children suffering from the coeliac disease [Wojtasik et al. 2009]. A study by Król et al. [2005] conducted on a group of healthy individuals following a conventional diet also showed an insufficient intake of calcium, potassium, magnesium and iron at excess amounts of phosphorus, while in contrast to the results of this study they showed an insufficient intake of zinc and copper and excess sodium. Similarly, Marzec et al. [2012] found too low contents of calcium, magnesium and potassium at excessive intake of sodium in the diets of university students.

Low intakes with the diet were also observed for vitamin D and folates. At the same time, the supply of a considerable group of vitamins exceeded the reference allowances. Excessive intakes were recorded for vitamins $\mathrm{A}, \mathrm{B}_{2}, \mathrm{PP}, \mathrm{B}_{6}$ and $\mathrm{B}_{12}$. In turn, Reguła et al. [2011] showed insufficient intake of most vitamins (folic acid, vitamins D, PP, $\mathrm{B}_{1}, \mathrm{~B}_{2}, \mathrm{~B}_{6}, \mathrm{C}$ ) in DFR of healthy adults.

At the administration of supplementation a considerable increase was observed for the intake of vitamins and minerals. The greatest differences in the intake of minerals were found for magnesium, zinc and iron. In turn, Marzec et al. [2011] stated that supplements have the most pronounced effect on the intake of zinc and magnesium. A year later the same author [Marzec et al. 2012] recorded the greatest improvement in the intake of calcium and magnesium as a result of introduced supplementation. In the case of vitamins the greatest differences were recorded for vitamins D, E, $\mathrm{B}_{6}$ and $\mathrm{C}$, which is confirmed by the results of other studies [Reguła et al. 2011]. Unfortunately, too low intakes were observed for potassium, calcium, iron and folates. At the same time the intake levels for practically all vitamins, except for folic acid, exceeded the limits of the reference allowances. In the case of minerals excessive intake levels of phosphorus, zinc and copper were observed as a result of supplementation. In a study by Reguła et al. [2011], exceeded intake allowances were also observed for vitamins $\mathrm{A}, \mathrm{E}, \mathrm{B}_{12}$ and $\mathrm{C}$ following the onset of supplementation. Tropmann et al. [2002] suggested a potential health hazard connected with excessive intake of vitamin A, PP and folates.

It needs to be stressed that both deficiency and excess of nutrients may have an adverse effect on human health [Reguła et al. 2011]. Among other things, high doses of vitamin $\mathrm{C}$ cause cristalluria, thus in individuals prone to kidney stones its intake should not exceed $100 \mathrm{mg}$ vit. $\mathrm{C}$ a day, while in healthy individuals it should be $1 \mathrm{~g}$ a day. Many researchers [Schlegel-Zawadzka and Barteczko 2009, Szotowa 2001, Sebastian et al. 2007] also stressed that supplementation is connected with a greater risk of oversupply of minerals and vitamins than their uptake from the diet. At the same time it is suggested that it is easy to exceed the allowance for vit. A, leading to side-effects [Szotowa 2001, Reguła et al. 2011]. Marzec et al. [2011] stated that $40 \%$ DFRs enriched with supplements led to excessively high levels of magnesium and zinc. In other studies [Marzec et al. 2012], allowances for magnesium, potassium and calcium were not exceeded; however, the frequently unjustified supplementation was also emphasized. Hozyasz et al. [2003] showed the need to assay concentrations of elements in blood of coeliac disease patients prior to the introduction of synthetic supplementation.

\section{CONCLUSIONS}

Results recorded in this study indicate that supplementation has a positive effect improving the percentage of reference intakes with DFR for minerals and vitamins and it has become very popular recently. However, the frequent use of preparations for prophylactic purposes, unconsulted with specialists, and the simultaneous administration of several supplements result in the allowances for these nutrients being exceeded. Thus we need to focus on the reasons for supplementation, which is also stressed by other authors [Hozyasz et al. 2003, Reguła et al. 2011, Marzec et al. 2012]. Unjustified use of dietary supplements may result in exceeded upper intake levels (UL) and lead to side-effects [Szotowa 2001, Reguła et al. 2011]. Thus it is necessary to assess the use of dietary supplements by different populations, including coeliac disease patients, in order to enrich the diet with vitamins and minerals to meet allowances for these nutrients.

In view of the conducted studies it should be stressed here that an appropriately balanced glutenfree diet may supply all essential nutrients in adequate amounts and - similarly as other researchers [Lemkin 2003, Autodore and Muralidhar 2009] - the authors 
of this study see the need to educate coeliac disease patients on nutritional issues.

\section{REFERENCES}

Autodore J., Muralidhar J., 2009. Celiac disease: a comprehensive review and update, series \#3. Nutritional complications of celiac disease. Pract. Gastroenterol. 33, 7, 34-39.

Bardella M.T., Fredella C., Prampolini L., Molteni N., Giunta A.M., Bianchi P.A., 2000. Body composition and diet ary intakes in adult celiac disease patients consuming a stricte gluten-free diet. Am. J. Clin. Nutr. 72, 937-939.

Gomułka K., Demkow U., 2010. Celiac disease - etiology, clinic and laboratory diagnostics. New Pediatrics 2, 44-49.

Grzymisławski M., Stankowiak-Kulpa H., Włochal M., 2010. Celiac disease - diagnostic and therapeutic standards 2010. Forum Metab. Disord. 1, 1, 12-21.

Hozyasz K., Ruszczyńska A., Bulska E., 2003. Concentrations of trace elements in patients with celiac disease. Fam. Med. 5, 154-155.

Janus P., Reguła J., 2011. The impact of selected environmental factors on the frequency of use of dietary supplements by persons aged 14-25 years. Adv. Food Proc. Techn. 1, 92-97.

Jarosz M., 2012 Nutrition standards for the population of Polish-amendment. Wyd. IŻŻ Warszawa.

Jóźwiak J., 2008. Rating of lipid profile, nutritional status and health awareness of the population covered by the care of family physicians. Application of statistical methods in research III. StatSoft Polska, 141-151.

Kliniczne aspekty żywienia $\mathrm{w}$ chorobach wewnętrznych [Clinical aspects of nutrition in internal medicine]. 2008. Ed. J. Chojnacki. Wyd. Univ. Med. Łódź [in Polish].

Kostrzewska M., Toporowska-Kowalska E., Kuchin J., Wąsowska-Królikowska K., 2007. The clinical presentation of celiac disease diagnosed after 4 years in own material of clinic allergy, gastroenterology and nutrition of children, Medical University of Lodz. Overview. Pediatrics 37, 2, 237-243.

Król E., Sobiech M., Krejpcio Z., 2005. The intake assessment of minerals in daily food rations selected group of vegetarians and nonvegetarians. Food Sci. Techn. Qual. 2 (43), 114-120.

Lemkin J., 2003. The emerging role of nutritional supplementation in celiac disease. Pioneer Health Education Library Shelburne Falls, MA, 1-6.
Lionetti E., Catassi C., 2011. New clues in celiac disease epidemiology, pathogenesis, clinical manifestations and treatment. Int. Rev. Immunol. 30, 219-231.

Marzec Z., Koch W., Marzec A., 2011. The intake assessment of magnesium and zinc by students of Lublin universities including diet supplementation. Bromatol. Chem. Toksykol. 44, 3, 561-566.

Marzec Z., Marzec A., Wyszogrodzka-Koma L., Buczek A., 2012. The intake assessment of calcium, magnesium, sodium and potassium with daily food rations of students including dietary supplements. Bromatol. Chem. Toksykol. 45, 3, 280-284.

Megiorni F., Pizzuti A., 2012. HLA-DQA1 and HLA-DQB1 in Celiac disease predisposition: practical implications of the HLA molecular typing. J. Biomed. Sci. 19, 88, $1-5$.

Reguła J., Gramza-Michałowska A., Stachowiak B., 2011. Participation of dietary supplements in nutrition of adults. Probl. Hig. Epidemiol. 92 (3), 614-616.

Scalon S.A., Murray J.A., 2011. Update on celiac disease etiology, drug target, and management advances. Clin. Exp. Gastroenterol. 4, 279-311.

Schlegel-Zawadzka M., Barteczko M., 2009. Evaluation of the use of natural supplements in healthy purposes by adults. Food Sci. Techn. Qual. 4 (65), 375-387.

Sebastian R.S., Cleverland L.E., Goldman J.D., Moshfegh A.J., 2007. Older adults who use vitamin supplements differ from nonusers in nutrient intake adequancy and dietary attitudes. J. Am. Diet. Assoc. 107, 8, 1322-1332.

Szajewska H., 2007. Can you prevent celiac disease? Allergy 3, 17-20.

Szotowa W., 2001. Tolerable upper intake levels of certain vitamins Pediatr. Contem. Gastroenter. Hepatol. Nutr. Child. 3, 2, 139-143.

Szponar L., Stoś K., Ołtarzewski M., 2007. Dietary supplements in nutrition of children and adolescents. Pediatr. Contem. Gastroenter. Hepatol. Nutr. Child. 9, 1, 41-44.

Tack G.J., Verbeek W.H.M., Schreurs M.W.J., Mulder G.J.J., 2010. The spectrum of celiac disease: epidemiology, clinical aspects and treatment. Nat. Rev. Gastroenterol. Hepatol. 7, 204-213.

Tropmann L., Gray-Donald K., Johns T., 2002. Supplements: is there any nutritional benefits? J. Am. Diet. Assoc. $102,6,818-825$.

Wojtasik A., Kunachowicz H., Socha J., 2009. Magnesium supplements and the need for their use in the diets of healthy children and celiac disease. Food Sci. Techn. Qual. 4 (65), 295-302. 


\section{UDZIAŁ SUPLEMENTÓW DIETY W ŻYWIENIU OSÓB CHORYCH NA CELIAKIĘ}

\section{STRESZCZENIE}

Wstęp. Celem pracy była ocena pobrania witamin i składników mineralnych z racji pokarmowej oraz po uwzględnieniu suplementacji u osób stosujących dietę bezglutenową.

Materiał i metody. W badaniach wzięło udział 25 osób w wieku od 20 do 54 lat. Badania przeprowadzono metodą ankietową. Zastosowano 24-godzinny wywiad oraz ankietę przygotowaną na potrzeby badania. Przeprowadzono także pomiary antropometryczne.

Wyniki i dyskusja. W dziennych racjach pokarmowych pacjentów z celiakią stwierdzono małą podaż energii oraz zbyt duży udział tłuszczu. Pobranie większości składników mineralnych z dietą było za małe, natomiast witamin - za duże. Większość badanych zadeklarowała stosowanie suplementów, które wniosły znaczny wkład w pokrycie zapotrzebowania na te składniki.

Wnioski. Zaobserwowano, że stosowana suplementacja była często nieuzasadniona, co doprowadziło do znacznego przekroczenia norm wielu witamin oraz składników mineralnych.

Słowa kluczowe: składniki odżywcze, dieta bezglutenowa, składniki mineralne, sposób żywienia

For citation - Do cytowania

Reguła J., Śmidowicz A., 2014. Share of dietary supplements in nutrition of coeliac disease patients. Acta Sci. Pol., Technol. Aliment. 13(3), 301-307. 